\title{
Smart Heritage in selected Australian local government smart city policies
}

\author{
David Batchelor ${ }^{1}$ and Marc Aurel Schnabel ${ }^{2}$ \\ ${ }^{1}$ Victoria University of Wellington, Wellington, New Zealand \\ david.batchelor@vuw.ac.nz \\ ${ }^{2}$ Victoria University of Wellington, Wellington, New Zealand \\ marcaurel.schnabel@vuw.ac.nz
}

\begin{abstract}
Smart Heritage leverages the past to transform cities into smart cities. It bridges a theoretical framework between the existing smart cities and heritage discourses and can benefit both the smart and heritage of aspirations of cities. The recent increase in the preparation of smart city policies by local governments in Australia provides an opportunity to examine how the recent generation of smart city strategic documents implement Smart Heritage. This paper will investigate how three local government smart city policies in Australia; City Futures Strategy by Logan City Council, Lake Mac Smart City Smart Council: Digital Economy Strategy 2016-2020 by Lake Macquarie City Council, and Smart, Connected Brisbane by Brisbane City Council; implement Smart Heritage. It will also briefly discuss the areas in the policies where further implementation of Smart Heritage can support the smart city ambitions of the cities.

The main findings are the policies subtly implement Smart Heritage, and it is most present in highlevel definitions and objectives. There is a need to develop Smart Heritage lower-level provisions and initiatives as there is a lack of these across the policies. Nevertheless, there is ample theoretical overlap between Smart Heritage and the policies to further implement Smart Heritage within the existing policy frameworks.
\end{abstract}

Keywords: Smart heritage; smart city; heritage.

\section{Introduction}

Smart Heritage is the next step in the evolution of smart cities as it identifies the past can have transformational power over how we shape and interact with environments. The transformational power of Smart Heritage, the theoretical bridging between the smart city and heritage discourses, stems from its position between its root-concepts. This position encourages data and smart technology to adopt the role of curator to form experiences about the past in present day smart cities for the benefit of both heritage and smart city outcomes. It moves the current discussion regarding technology and heritage beyond the passivity that is dominant in Digital Heritage and enables a new paradigm for understanding and experiencing the past; potentially challenging authorised heritage discourses and the role of historical narratives in the city.

Revisiting the Role of Architecture for 'Surviving' Development. 53 ${ }^{\text {rd }}$ International Conference of the Architectural Science Association 2019, Avlokita Agrawal and Rajat Gupta (eds), pp. 245-254. (C) 2019 and published by the Architectural Science Association (ANZAScA). 
To adequately apply and benefit from Smart Heritage it is important to firstly understand how smart cities are implementing the concept so context can be found to develop the concept through later discussions. This paper will therefore investigate how the smart city policies of Logan City Council, Lake Macquarie City Council, and Brisbane City Council implement Smart Heritage, and briefly discuss the areas in the policies where further implementation of Smart Heritage can support their ambitions.

This research comes at a time of expansion within the Australian smart city sector resulting from the \$50 million in funding for local governments by the Australian Government in 2016 as part of its Smart Cities and Suburbs Program (Australian Government, 2018). This program supports the delivery of smart city projects that address liveability, productivity, and sustainability. The program encourages local governments to prepare and adopt smart city policies that outline how they will manage and implement the smart city projects within their jurisdictions. Each policy provides a definition of a smart city in their context, and objectives, provisions, and initiatives to deliver their smart city ambitions.

\section{What is Smart Heritage?}

Smart Heritage is the "theoretical convergence of heritage, a value-based concept resulting from the understood transmission of significance associated with the past, and smart city, a recognised area that automatically implements information through digital technology to benefit those interacting with and within that area" (Batchelor and Schnabel, 2019). It is a portmanteau term of 'smart city' and 'heritage' that bridges between both concepts. It forms a relationship between the concepts where the elements of both intersect, converse, and find value. For example, heritage can benefit the application of smart cities, and smart city applications enhance heritage outcomes.

Inherit within the 'smart' component of the term, are the elements of and applications for communication, sustainability, wellbeing, infrastructure, community, systems, and economy (Nam and Pardo, 2011; Chourabi et al., 2012; Yigitcanlar et al., 2018). Other occasionally present elements and applications are mobility, human capital, governance, access, efficiency, and urban space. The 'heritage' component contributes elements of subjective and malleable values associated with the past that are subject to personal and collective understandings within changing environments (Smith, 2006; Smith and Waterton, 2009; Uzzell, 2009; Winter, 2012). Simply put, Smart Heritage leverages that meaning associates with the past in smart city contexts.

Smart Heritage advances the discussion at the intersection of technology and heritage, currently occupied by Digital Heritage and Virtual Heritage, as it draws on the automatic implementation of information inherit within the smart city concept. The concept applies decision-making technology that does not require constant human input, commands, or oversight. For Smart Heritage, this may include, but is not limited to, sourcing data from a user, heritage resources, and real-time environments to improve the experience and understanding of significance associated with the past for that user. Smart Heritage also involves applications such as the automatic implementation big data to improve communication and engagement processes for historical resources and narratives. In comparison, Digital Heritage lacks this automatic implementation and is passive due to its reliance on humans to command the transmission of significance through activating digital files, such as on audio guides or mobile applications (UNESCO, 2003). Virtual Heritage is similarly passive as it is focuses on the transmission of historical realities using visual imaging technology and lacks meaningful decision-making abilities for curating a heritage experience (Roussou, 2002). 
The theoretical grounding of Smart Heritage embraces post-modern criticisms of heritage. It enables authorized heritage discourses to be challenged by positioning technology as the curator of heritage experiences rather than an institution or human (Smith, 2006). In this role, and because Smart Heritage applications may rely on big data and changing information sources, it may lead to alterative historical narratives occurring for the purposes of improving engagement, finding value and meaning in the past which diverges from authorised narratives. Smart Heritage therefore may discover different perspectives and alternative truths due to the large, unauthorised, and evolving nature of big data (Viñas, 2002).

\section{Research Design}

This research draws on similar studies by Angelidou et al. (2017) which investigates and compares the integration of heritage in the smart city policies of Barcelona, London, and Amsterdam. This research therefore similarly applies a cross-case analysis to investigate the implementation of Smart Heritage in three local government smart city policies from Australia. This method enables the comparative assessment of similar cases to identify trends, relationships and extract propositions (Yin, 2003; Eisenhardt, 1989).

The research firstly identifies the relevant components in the policies; their smart city definition, and the objectives, provisions, and initiatives that include or support Smart Heritage elements and outcomes. For clarity, a smart city definition is where the policy clearly states what a smart city is, objectives are high level statements such as key principles or aims, provisions are mid-level statements, and initiatives are real-world applications or deliverables. The research records the differences in terminology of the components and assigns it to the most relevant category for the purposes of this cross-case analysis. A table presents the data to display the information and allow its comparative analysis.

Secondly, scanning of the table occurs to uncover trends and patterns within the policies. A discussion then presents how the policies collectively implement Smart Heritage, focusing on the trends and differences throughout the policies, before statements on where further implementation of Smart Heritage can support the smart city ambitions of the cities.

This paper investigates the following cases:

- City Futures Strategy, Logan City Council (2018);

- Lake Mac Smart City Smart Council: Digital Economy Strategy 2016-2020, Lake Macquarie City Council (2016); and

- Smart, Connected Brisbane, Brisbane City Council (2017)

The reasons for the selection of each policy is that each policy is operative within their jurisdiction, all policies relate to areas that have a record of human history and settlement from both Aborigines and settlers, and the cities contain populations that are of a notable size; over 200,000 inhabitants each. The operative status is important because many other local governments in Australia are still drafting their policies. The presence of known history enables historical narratives to intersect with the smart city ambitions of the city for Smart Heritage to become relevant for inclusion in the policies. The notable population size of the cities indicates the cities have a significant scale of smart city aspirations and the ability to deliver Smart Heritage outcomes. 


\section{Research}

The following section briefly describes each policy, their smart city definitions, and the relevant objectives, provisions, and initiatives. Table 1 presents the relevant policy components; definitions, provisions, objectives, and initiatives.

\subsection{City Futures Strategy, Logan City Council (2018)}

The City Futures Strategy by Logan City Council (2018) defines a smart city as one "that apply digital technology, big data, community empowerment, and innovative thinking to improve liveability, sustainability and productivity". The policy provides four objectives. The objective 'empowering knowledge' is relevant to Smart Heritage as it seeks to "encourage and increase participation, harness the knowledge and creativity of our community, and design services that are people-centric". The objective 'confidence' is also relevant because it seeks a city that is proud of its history and unique identity. The other objectives mention the 'innovation', 'disruption', and 'technology' but do not clearly state elements of Smart Heritage, therefore, they are not feature in the data collection.

The policy provides nine provisions that each have between four to nine progress indicators. Provisions that are relevant to Smart Heritage include elements of digital connectivity, city vibrancy and visitation, and community inclusion and participation. The policy has five areas of initiatives, identified as priority actions in the policy, with eight to ten initiatives each. The areas with relevant initiatives are 'future innovation and prosperity', 'future connectivity', 'future community', and 'future place'. The relevant initiatives to Smart Heritage relate to implementing open data programs, improving data usage, creating smart city platforms, engaging the community through digital technology, and using digital technology to support culture, arts, and tourism and city activation.

\subsection{Lake Mac Smart City Smart Council: Digital Economy Strategy 2016-2020, Lake Macquarie City Council (2016)}

Lake Mac Smart City Smart Council by Lake Macquarie City Council (2016) states that "a smart city captures the diverse ways in which new online technologies are shaping how we work, collaborate, play, innovate and plan for the future". The policy has four objectives, named principles in the policy, which guide the strategy. There are two objectives that are relevant for this research; titled 'activate', which seeks empower the community through flexibility and experimentation, and 'build', which seeks to upgrade information technology infrastructure and systems across the city. The other objectives do not address matters that are relevant for Smart Heritage.

The policy provides five provisions, identified as strategic outcomes. The provision of 'connected communities' is relevant to Smart Heritage as it seeks to implement and improve broadband services and information management systems. The provision 'great places' is also relevant as it aims to use digital technology to build a sense of community and place. The other provisions are not relevant as they focus on online council services, business innovation and investment culture, and digital literacy.

Each provision has three or four initiatives below it. For 'connected communities', the relevant initiatives for Smart Heritage are installing broadband services across the city, upgrading existing council information management systems to improve internal productivity and adapt to future networks, trial and implement environmental data collection to improve decision making, and creating council guidelines for utilising third party technology. The relevant initiatives for 'great places' are piloting interpretative historical and cultural information applications, investigating interactive art and light 
projects to enhance public spaces, and improve experiences for online council and local business services through systems data sharing and internal optimisation.

\subsection{Smart, Connected Brisbane, Brisbane City Council (2017)}

Smart, Connected Brisbane by Brisbane City Council (2017) defines a smart city as "a city that utilises information and communication technologies to meet the demands of its citizens while enhancing quality of living". The policy identifies six objectives, named as characteristics, that are central to its vision of a smart city. The objectives that reflect Smart Heritage are 'efficient', where "digital technologies are employed to make activities efficient and effective", 'personalised', where "people have a personalised human, experience within the city", and 'insightful' where "analytics creates insights that enable data-drive decision making". The other objectives do not significantly relate to Smart Heritage; they address economic prosperity, social inclusivity, and a social environment of trust and innovation.

There are sixteen provisions, identified as goals, in the policy. They cover three focus areas of 'explore and understand', 'deliver and implement' and 'upskill'. The relevant provisions for Smart Heritage relate to improving accessibility and usage of data to improve users' digital and city experiences. There are eight initiatives in the policy. The relevant initiatives for Smart Heritage are the installation of public Wi-Fi services throughout the city and the release of council data to support innovation. The other initiatives relate to entrepreneurship, water usage, council procurement processes, transport, food trucks, and emergency services and are not particularly relevant for Smart Heritage.

Table 1 presents the components from each case. The table presents the policies vertically and divides them horizontally into definitions, objectives, provisions, and initiatives.

Table 1: Tabular display of the three cases

\begin{tabular}{|c|c|c|c|}
\hline & $\begin{array}{l}\text { City Futures Strategy, Logan } \\
\text { City Council (2018) }\end{array}$ & $\begin{array}{l}\text { Lake Mac Smart City Smart } \\
\text { Council: Digital Economy } \\
\text { Strategy 2016-2020, Lake } \\
\text { Macquarie City Council (2016) }\end{array}$ & $\begin{array}{l}\text { Smart, Connected Brisbane, } \\
\text { Brisbane City Council (2017) }\end{array}$ \\
\hline Definition & $\begin{array}{l}\text { (Smart) cities and communities } \\
\text { that apply digital technology, } \\
\text { big data, community } \\
\text { empowerment, and innovative } \\
\text { thinking to improve liveability, } \\
\text { sustainability and productivity. }\end{array}$ & $\begin{array}{l}\text { A smart city captures the diverse } \\
\text { ways in which new online } \\
\text { technologies are shaping how we } \\
\text { work, collaborate, play, innovate } \\
\text { and plan for the future" }\end{array}$ & $\begin{array}{l}\text { A city that utilises information and } \\
\text { communication technologies to } \\
\text { meet the demands of its citizens } \\
\text { while enhancing quality of living }\end{array}$ \\
\hline Objectives & $\begin{array}{l}\text { Empowering community: We } \\
\text { will work to encourage and } \\
\text { increase participation, harness } \\
\text { the knowledge and creativity of } \\
\text { our community, and design } \\
\text { services that are people- } \\
\text { centric. } \\
\text { Confidence: The City of Logan }\end{array}$ & $\begin{array}{l}\text { Active: Activating the Smart City } \\
\text { and empowering the community } \\
\text { requires a certain degree of } \\
\text { flexibility and experimentation, } \\
\text { which government policy can } \\
\text { facilitate } \\
\text { Build: Council and partner } \\
\text { government and industry }\end{array}$ & $\begin{array}{l}\text { Efficient: Digital technologies are } \\
\text { employed to make activities } \\
\text { efficient and effective } \\
\text { Personalised: People have a } \\
\text { personalised human experience } \\
\text { within the city }\end{array}$ \\
\hline
\end{tabular}




\begin{tabular}{|c|c|c|c|}
\hline & $\begin{array}{l}\text { is a city of confidence. We are } \\
\text { proud of our history, and look } \\
\text { forward to our future with } \\
\text { excitement and optimism. Our } \\
\text { city will be confident in our } \\
\text { strengths and our unique } \\
\text { identity, and confident as we } \\
\text { embark on new paths of } \\
\text { opportunity and innovation. }\end{array}$ & $\begin{array}{l}\text { stakeholders will facilitate the } \\
\text { upgrade of information } \\
\text { technology infrastructure and } \\
\text { systems across the City }\end{array}$ & $\begin{array}{l}\text { Insightful: Analytics creates insight } \\
\text { that enables data-driven decision } \\
\text { making }\end{array}$ \\
\hline Provisions & $\begin{array}{l}\text { To increase the quality and } \\
\text { coverage of digital connectivity } \\
\text { To increase city vibrancy, } \\
\text { visitation and activation } \\
\text { To improve community } \\
\text { inclusion and participation }\end{array}$ & $\begin{array}{l}\text { Connected communities: a city of } \\
\text { connected communities and } \\
\text { smart city services: } \\
\text {-New technologies can provide } \\
\text { the scale that allows greater, } \\
\text { more efficient access to services } \\
\text { and information and significantly } \\
\text { enhance government } \\
\text { engagement with a } \\
\text { geographically dispersed } \\
\text { population. } \\
\text {-Connecting communities with } \\
\text { better information about the } \\
\text { City and what it has to offer is } \\
\text { also key. } \\
\text { Great Places: a city with great } \\
\text { places to meet and connect: } \\
\text {-A Smart City is one where it is } \\
\text { easy to connect both online and } \\
\text { in person. This combination } \\
\text { drives innovation, builds a sense } \\
\text { of community and makes cities } \\
\text { fun and interesting }\end{array}$ & $\begin{array}{l}\text { Explore and understand: Explore } \\
\text { and create meaning out of our city's } \\
\text { data } \\
\text { Explore and understand: } \\
\text { Understand the city and its people } \\
\text { through the data they create } \\
\text { Explore and understand: Use data } \\
\text { to inform decision making } \\
\text { Deliver and implement: Predict and } \\
\text { deliver inclusive, tailored digital } \\
\text { experiences for Brisbane's } \\
\text { residents, businesses and visitors } \\
\text { Upskill: Integrate smart, connected } \\
\text { seamlessly into everyday life to } \\
\text { enrich the lives of residents, } \\
\text { businesses and visitors } \\
\text { Upskill: Use integrated data and } \\
\text { real time analytics to inform } \\
\text { decisions and improve services }\end{array}$ \\
\hline Initiatives & $\begin{array}{l}\text { Future innovation and } \\
\text { prosperity: We will enhance } \\
\text { our open data program and } \\
\text { leverage the Internet of Things } \\
\text { and big data to build a more } \\
\text { efficient, innovative and } \\
\text { dynamic city } \\
\text { Future connectivity: We will } \\
\text { work with industry and } \\
\text { innovators, leveraging existing } \\
\text { infrastructure, such as } \\
\text { streetlights, to create a smart } \\
\text { city connectivity platform } \\
\text { Future community: We will }\end{array}$ & $\begin{array}{l}\text { Connected communities: } \\
\text { Investigate merit in improving } \\
\text { high-speed broadband } \\
\text { infrastructure } \\
\text { Connected communities: } \\
\text { Investigate opportunities for } \\
\text { incorporating smart technologies } \\
\text { to collect, transmit and retrieve } \\
\text { anonymous data on asset use, } \\
\text { resource consumption and } \\
\text { maintenance activity to inform } \\
\text { city management and strategic } \\
\text { planning } \\
\text { Connected communities: Develop } \\
\text { guidelines with criteria for }\end{array}$ & $\begin{array}{l}\text { Open data: Brisbane City Council } \\
\text { releases open data free of charge to } \\
\text { encourage third parties to } \\
\text { develop apps, websites and tools } \\
\text { that can benefit Brisbane residents } \\
\text { and business. } \\
\text { Free Wi-Fi network: Council's } \\
\text { free Wi-Fi service allowing residents } \\
\text { and visitors to stay connected as } \\
\text { they move around many parks and } \\
\text { public spaces across the city, }\end{array}$ \\
\hline
\end{tabular}




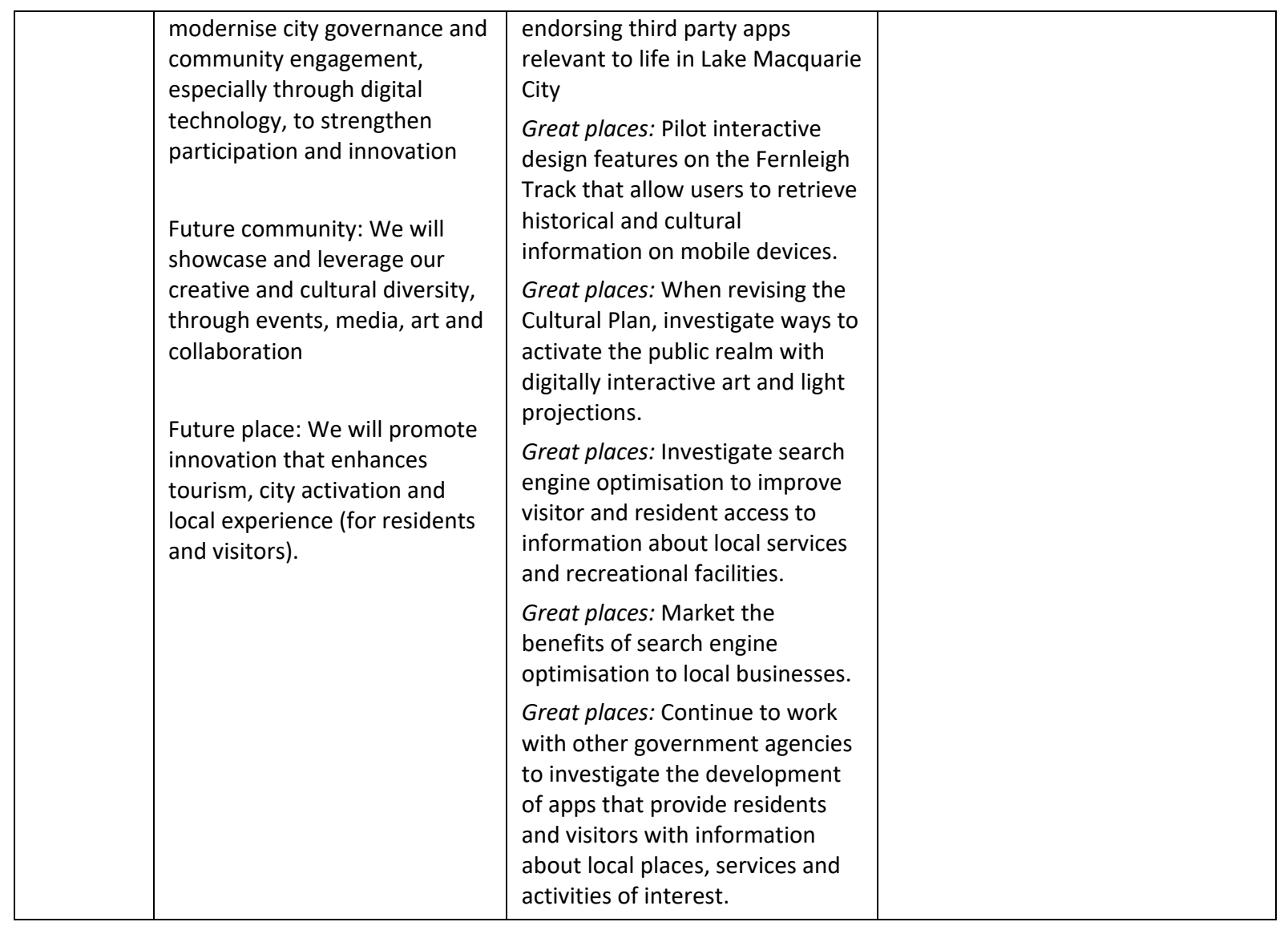

\section{Analysis of Findings and Discussion}

The first finding is the policies do not explicitly implement Smart Heritage. However, it is subtly present in the policies through the combination of complementary components. For example, in City Futures Strategy by Logan City Council (2018) the combination of the big data, community empowerment and liveability elements in its definition, the emphasis of the city's past and unique identity its objectives, and the provisions and initiatives to increase city vibrancy, visitation, and activation builds a strong case for the presence of Smart Heritage. Smart, Connected Brisbane by Brisbane City Council (2017) builds a Smart Heritage discourse through its provisions and objectives that seek to employ a personal human experience, data-drive decision making, and meaning within the smart city context. However, this discourse does not explicitly relate to heritage or Smart Heritage matters and therefore is likely unintentional. Lake Mac Smart City Smart Council by Lake Macquarie City Council (2016) does not provide clear indicators of the Smart Heritage concept, however, its definition and broad policy components that focus on community and place-making do not exclude the exploration of Smart Heritage by future initiatives. 
A second finding is the smart city definitions and objectives shape the scope available for the lowerorder provisions and initiatives. This shaping can either broad or restrict the scope for the lower components and then influence their effectiveness for Smart Heritage. For example, the definitions and objectives in City Futures Strategy and Lake Mac Smart City Smart Council emphasise the primary role of the council as the administrator or manager of the smart city discourse, excluding business owners and the community from significant input. This scope leads the policy to deliver outcomes that are within the control of council, such as publicly owned cultural institutions and tourism ventures, council-led place-making activities, and public space infrastructure and service improvements. In these policies therefore restrict the scope for Smart Heritage by this top-down approach. In comparison, the definition and objectives in Smart, Connected Brisbane position technology as the leading elements in the policy and does not state who will control or initiate the technology; leaving it open to all parties in the city. As a result, the provisions and initiatives are less prescriptive about outcomes. This enables greater flexibility for Smart Heritage where it can apply to all sectors where meaning and the past intertwine with smart city aspirations, including and beyond council-controlled measures. This is especially notable in the provisions that tailor digital experiences and create meaning out of the city's data in Smart, Connected Brisbane. Flexibility for Smart Heritage is therefore important as it enables the concept to find its own value within the social, economic, political, and contextual environment within each city.

A third finding is there is little meaningful implementation of Smart Heritage in the initiatives across the policies. The policies do not convey the sentiment of Smart Heritage present in their objectives and provisions into tangible outcomes in their initiatives. For example, the tourism and event-focused initiatives in City Futures Strategy only partially reflect the aspirations in the definitions and objectives that mix digital technology, big data, community empowerment, innovative thinking and overt connection with the past, community, and innovation. In this case, the initiatives could adopt a wider focus for applying the concept, such as for enhancing liveability, cultural richness, and civic identity, and supporting the conservation of historical resources. Smart, Connected Brisbane also does not deliver initiatives that build on the emphasis on personal experiences and meaning in its objectives and provisions. It is unclear whether and in what form the policy will deliver Smart Heritage, however, the strong integration of Smart Heritage in the objectives and provisions signal it will occur. Lake Macquarie City Council notably includes an initiative to retrieve historical and cultural information on mobile devices, however, this is likely to be Digital Heritage due the initiative stating users will retrieve the information, likely from pre-set digital archives, rather than the technology having a greater curator role. All the policies do not include initiatives that leverage meaning that associates with the past in smart city contexts.

Regarding the possible further implementation of Smart Heritage in the policies, there is ample theoretical overlap between the policies and the concept for the further adoption of Smart Heritage. Each smart city definition given in the policies being sufficiently broad to promote or enable the application of meaning that associates with the past into applications within a smart city. While the definitions are not explicitly in favour of Smart Heritage, they do not exclude or restrict its implementation. The difficulty to explicitly implement Smart Heritage in a definition that also covers all facets of a smart city is understood.

The policies require the further implementation of contextual meaning within a smart city context to improve the presence of Smart Heritage. Only Logan City Council mentions the past explicitly out of the three policies. For example, altering the objective in Smart, Connected Brisbane to 'Personalised: People connect, experience and contribute to narrative of the city'. Emphasising contextual meaning, such as 
the narrative of the city and its people, can provide guidance to lower order components without restricting the objective too specifically for Smart Heritage outcomes.

The provisions require a more explicit approach to the implementation of Smart Heritage than what is currently present. Yet, these are to be within the context of their above objectives. The provisions should aim to emphasise concepts associated with the past and their benefits for liveability, economic growth, innovation, civic identity, and wellbeing. For example, Logan City Council could adopt or modify a provision that features the proud history of the city and harnessing the knowledge and creativity of its community that the above objective states. The policy from Lake Macquarie City Council could adopt a provision that emphasises the historic identity of the various communities and their contribution to the story of the wider city. This would link well with the above 'Connected communities' objective. The provisions of Brisbane City Council are strong and sufficiently integrate Smart Heritage.

The initiatives require more direct implementation to meaningfully apply Smart Heritage. For example, Brisbane City Council could adopt an initiative that uses data analytics to identify heritage significance in archival, news, and online sources to create new dialogue and information to personalise and enrich the city. An initiative like this would align with its provisions and objectives which indicate Smart Heritage outcomes. The tourism-focused initiative in the policy from Logan City Council could employ contextual meaning and the identity of the city to achieve greater city activation. The initiatives in the policy from Lake Macquarie City Council could better position information and digital technology as the curator in heritage experiences to make better places.

\section{Conclusion}

The research finds the smart city policies of Logan City Council, Lake Macquarie City Council, and Brisbane City Council do not explicitly implement Smart Heritage; however, it is subtly present in the policies through the combination of complementary components. Also, the smart city definitions and objectives influence the scope of the implementation in the lower order provisions and initiatives by focusing the application of Smart Heritage to specific topics and contexts. The research also finds little meaningful implementation of Smart Heritage in the initiatives across the policies. This raises the question whether there is significant awareness of the methods to implement the concept in local government smart city policies?

In addition, there is ample theoretical overlap between the policies and Smart Heritage to enable further implementation of the concept as a result of them sharing many of the same elements and outcomes. Further implementation is possible in the objectives, provisions, and the initiatives through the layering of Smart Heritage concepts in greater specificity from the objectives towards the initiatives. The given definitions appear sufficient for the further implementation of the concept.

Further research on additional policies will be valuable to provide a more comprehensive understanding on the implementation of Smart Heritage across the Australian local government smart city sector. A more comprehensive understanding will benefit the implementation of the concept to achieve both civic and heritage aspirations in smart city contexts; a need which this research identities as beneficial to address the lack of meaningful initiatives in the policies. Smart Heritage will likely require further development before local government smart city policies explicitly implement it. The exact form of the implementation will likely vary depending on the context of each city. 


\section{References}

Angelidou, M., Karachaliou, E., Angelidou, T., and Stylianidis, E. (2017) 'Cultural heritage in smart city environments', 26th International CIPA Symposium 2017. Ottawa, Canada, 28 August-01 September 2017. The International Archives of the Photogrammetry Remote Sensing and Spatial Information Sciences: pp. 27-32.

Australian Government. (2018) Smart Cities and Suburbs Program. Available from: https://cities.infrastructure.gov.au/smart-cities-program. (accessed 20 May 2019).

Batchelor, D., and Schnabel, MA. (2019) 'Smart Heritage: The convergence of heritage and the smart city, Digital Cultural Heritage: FUTURE VISIONS a landscape perspective. Shanghai, China, 23 and 24 November, Shanghai: Tongii University and University of Queensland, under review.

Brisbane City Council. (2017) Smart, Connected Brisbane. Available from: https://www.brisbane.qld.gov.au/aboutcouncil/governance-and-strategy/vision-and-strategy/smart-connected-brisbane. (accessed 20 May 2019).

Chourabi, H., Nam, T., Walker, S., Gil-Garcia, J.R., Mellouli, S., Nahon, K., Pardo, T. and Scholl, H. (2012) 'Understanding Smart Cities: An Integrative Framework', 45th Hawaii International Conference on System Sciences. Maui, USA, 4-7 January. Washington DC: IEEE, pp. 2289-2297.

Eisenhardt, K. M. (1989) Building theories from case study research. Academy of management review, 14(4), pp. 532-550.

Lake Macquarie City Council. (2016) Lake Mac Smart City, Smart Council: Digital Economy Strategy 2016-2020. Available from: https://shape.lakemac.com.au/smart-city (accessed 20 May 2019).

Logan City Council. (2018) City Futures Strategy. Available from: https://www.logan.qld.gov.au/about-logan/livingin-logan/innovation. (accessed 20 May 2019).

Nam, T. and Pardo, T. (2011) 'Conceptualizing smart city with dimensions of technology, people, and institutions', 12th Annual International Digital Government Research Conference: Digital Government Innovation in Challenging Times. Maryland, USA, 12-15 June. New York: ACM, pp. 282-291.

Roussou, M. (2002) 'Virtual Heritage: From the Research Lab to the Broad Public', Virtual Archaeology: Proceedings of the VAST 2000 Euroconference. Arezzo, Italy, 24-25 November. Arezzo: Archaeopress, pp. 93-101.

Smith, L, and Waterton. E. (2009) 'The envy of the world?' Intangible heritage in England'. in Smith, J. and Akagawa, N. (eds) Intangible Heritage. London: Routledge, 289- 302.

Smith, L. (2006) Uses of Heritage. Abingdon: Routledge.

United Nations Educational, Scientific and Cultural Organisation (UNESCO). (2003) Charter on the Preservation of Digital Heritage. Available at: https://unesdoc.unesco.org/ark:/48223/pf0000179529. (accessed 20 May 2019).

Uzzell, D. (2009) 'Where is the discipline in heritage studies? A view from environmental psychology'. in Sorensen, MLS. and Carman, J. (eds) Heritage Studies: methods and approaches. Abington: Routledge, pp. 326-333.

Viñas, S.M. (2002) 'Contemporary theory of conservation', Studies in Conservation, 47(1), pp. 25-34.

Winter, T. (2012) 'Clarifying the critical in critical heritage studies', International Journal of Heritage Studies, 19(6), pp. $532-545$.

Yigitcanlar, T., Kamruzzaman, M., Buys, L., loppolo, G., Marques, J., Moreira Da Costa, E. and Yun, J. (2018) 'Understanding 'smart cities': Intertwining development drivers with desired outcomes in a multidimensional framework', Cities, 81, pp. 145-160.

Yin, R. (2003) Case Study Research: Design and Methods. London: SAGE Publications. 